\title{
Genetic variability of four natural isolates of the Stilpnotia salicis multiple-enveloped nuclear polyhedrosis virus*
}

\author{
Ludmiła Strokovskaya $^{a}$, Jadwiga Ziemnicka ${ }^{b}$, Joanna Michalik ${ }^{c}$

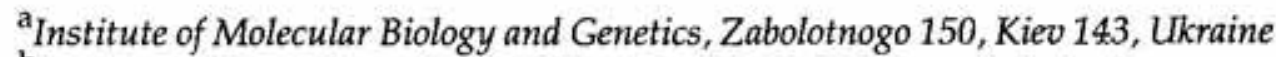 \\ bInstitute of Plant Protection, A. Miczurina 20,60-318 Poznañ, Poland \\ ${ }^{c}$ Institute of Biochemistry and Biophysics, Polish Academy of Sciences, \\ A. Pawiniskiego 5a, 02-106 Warsaw, Poland
}

Received: 9 August, 1996

Key words: nuclear polyhedrosis virus, Stilpnotia salicis, baculovirus natural isolates, restriction analysis

\begin{abstract}
Viral genome DNA from four different multiple-enveloped nuclear polyhedrosis virus isolates, obtained from naturally infected larvae of satin moth (Stilpnotia salicis), $a$ pest of poplar tree (Populus) was analysed. Larvae were collected over a period of 11 years, from 1978 to 1989 . The genomic DNA restriction patterns pointed to heterogeneity of these wild-type viruses. The differences observed in isolates of several years revealed limited restriction fragment length polymorphism and showed that these viruses contained distinct, but closely related genotypes. The genome size of SsMNPV was established as 128-134 kb, based on HindIII and SacI restriction analysis.
\end{abstract}

Baculoviruses infecting invertebrates, mainly insects, are big viruses of complicated structure and life cycle, carrying double-stranded covalently closed DNA [1, 2]. The size of their DNA ranging from 88 to $180 \mathrm{kbp}$, is usually characteristic for the particular type of virus isolated from its host $[3,4]$. In nature, baculoviruses are natural insect pathogens having a narrow host range limited mainly to Lepidoptera (butterflies). The majority of insect pests belongs to this order.

Baculoviruses are an efficient and ecologically safe means of controling the pests populations. From this point of view a natural viral pathogen of Stilpnotia salicis, the nuclear polyhedrosis virus, SsMNPV was examined as a biological agent in fighting this pest [5, 6]. For possible use of baculoviruses as insecticides a knowledge of their structural and genetic character is required. Morphology and microscopic analysis of SsMNPV polyhedra were described several years ago [7] in natural isolates of this virus appearing on Polish territory. However, there is no information concerning biochemical anaIysis of this virus, viral genome characteristics or type of occluded proteins. In this paper we describe the structure and size of SsMNPV viral genome studied by restriction analysis, a simple and widely used method for characterization and identification of baculoviruses from the Baculoviridae family $[8,9]$.

"This work was supported, in part, by the Polish-French Biotechnology Centre (CNRS, KBN, grant No. C-2/II/06).

Correspondence to: Dr Joanna Michalik, Institute of Biochemistry and Biophysics, Polish Academy of Sciences, A. Pawińskiego 5a, 02-106 Warsaw, Poland

Abbreviations: SsMNPV, Stilpnotia salicis multiple-enveloped nuclear polyhedrosis virus; AcMNPV, Autographa californica multiple-enveloped nuclear polyhedrosis virus. 


\section{MATERIAL AND METHODS}

Virus. SsMNPV was obtained from infected last instar larvae of satina moth, Stilpnotia salicis, collected in: 1978 (DNA-I), 1980 (DNAII), 1987 (DNA-III) and 1989 (DNA-IV).

Isolation and purification of polyhedra. Polyhedra were obtained from dried larvae kept at $4^{\circ} \mathrm{C}$. Larvae were homogenized in $1 \%$ SDS water solution and filtered through two layers of cheesecloth. The filtrate was centrifuged at 10000 r.p.m. for $30 \mathrm{~min}$. The pellet was suspended in TE buffer $(10 \mathrm{mM}$ Tris $/ 1 \mathrm{mM}$ EDTA, pH 8.0) and $10 \mathrm{ml}$ portions were layered onto a two-step sucrose gradient of $20 \mathrm{ml} 50 \%$ $(\mathrm{w} / \mathrm{w})$ and $6 \mathrm{ml} 60 \%(\mathrm{w} / \mathrm{w})$ sucrose. After centrifugation in an SW 28 Beckman rotor at 24000 r.p.m. for $60 \mathrm{~min}$, the polyhedra were collected at the interface between $50 \%$ and $60 \%$ sucrose. Polyhedra were subsequently washed three times with distilled water and the final pellet was resuspended in water and stored at $4^{\circ} \mathrm{C}$. The amount of polyhedra was calculated in a standard chamber hemocytometer. Occasionally, the polyhedra were obtained without purification in the sucrose density gradient.

Isolation of viral DNA. DNA of SsMNPV was isolated from polyhedra according to the modified method of Cherepenko \& Martynenko [10]. The modification, based on including the 0.05 $M$ EDTA and proteinase $\mathrm{K}$ into the DNA isolation solution, permitted to isolate undegraded, protein free virus DNA from a small quantity of collected material. The minimal amount of material that can be used for DNA isolation by this method is $10^{9}$ polyhedra or $10 \mathrm{mg}$. The pellet containing polyhedra was suspended in $100 \mu \mathrm{l}$ of $50 \mathrm{mM}$ EDTA, pH 8.0, and supplemented with equal volume of the solution for DNA isolation consisting of: $125 \mu \mathrm{l}$ spermidine ( $2 \mathrm{mg} / \mathrm{ml}), 40 \mu \mathrm{l}$ ethidium bromide (10 $\mathrm{mg} / \mathrm{ml}), 50 \mu \mathrm{l} 0.5 \mathrm{M}$ EDTA, $\mathrm{pH} 8.0$, and $285 \mu \mathrm{l}$ $\mathrm{H}_{2} \mathrm{O}$. To this mixture, a solution of $0.2-0.5 \mathrm{M}$ $\mathrm{NaOH}$ was added in small portions $(5-10 \mu \mathrm{l})$ up to $\mathrm{pH} 11.0$, with very gentle stirring after addition of each drop. As DNA is released from polyhedra, the lysate should become viscous and clear. Subsequently, the $\mathrm{pH}$ of the mixture was adjusted to $8.5-9.0$ with $0.1 \mathrm{M} \mathrm{HCl}$. For protein hydrolysis proteinase $\mathrm{K}$ was added to a concentration of $200 \mu \mathrm{g} / \mathrm{ml}$ and incubation performed at $37^{\circ} \mathrm{C}$ for $60 \mathrm{~min}$. Then $10 \%$ SDS was added to a final concentration of $1 \%$ and the incubation continued for another $60 \mathrm{~min}$. DNA was extracted with an equal volume of phenol/chloroform (50:50, v/v, equilibrated with $50 \mathrm{mM}$ Tris/ $\mathrm{HCl}, \mathrm{pH} 8.0$ ), avoiding violent shaking as this shears the high molecular mass virus DNA. The phases were separated by spinning for $5 \mathrm{~min}$ in a microfuge. The extraction procedure was repeated twice. The water phase was placed in a fresh tube and supplemented with 2 vol. of absolute ethanol. DNA was recovered from this solution by winding up on a glass rod, washed three times with $75 \%$ ethanol and air dried. Then the rod with DNA on it was placed in $100 \mu \mathrm{l}$ of TE buffer and kept at $4^{\circ} \mathrm{C}$ overnight. Usually such a procedure led to total dissolution, without any degradation of high molecular mass viral DNA.

Analysis of virus DNA with restriction endonucleases. DNA isolates before restriction analysis were characterized by electrophoresis in $0.8 \%$ agarose gels containing ethidium bromide $(0.5 \mu \mathrm{g} / \mathrm{ml})$. The DNA probe $(1 \mu \mathrm{g})$ was mixed with $1 \mu \mathrm{g}$ of ethidium bromide and loaded on a gel. Electrophoresis was carried out at $50 \mathrm{~V}$ for $60 \mathrm{~min}$. Viral DNA was digested with restriction enzymes: BamHI, KpnI, EcoRI, PstI, Xhol, HindIII, SalI, SacI (Fermentas, Lituania) in appropriate reaction buffers and incubated for $3-4 \mathrm{~h}$ at $37^{\circ} \mathrm{C}$. The restriction products were separated in $0.7 \%$ agarose gel in TBE buffer (0.089M Tris/boric acid, 0.002 MEDTA, $\mathrm{pH} 8.0$ ) at $30 \mathrm{~V}$ for $18 \mathrm{~h}$.

\section{RESULTS}

\section{Characteristics of viral DNA preparation}

The electrophoresis of baculovirus DNA performed in the presence of ethidium bromide revealed differences not only in the size of DNA, but also in the presence of several forms of viral DNA molecules [11]. The following DNA structures could be distinguished: a) circular, relaxed forms located in the loading slots, b) covalently closed forms, migrating slowly in agarose gel, and c) linear forms migrating more rapidly than forms $a$ ) and $b$ ). In the absence of ethidium bromide both forms of circular DNA did not migrate in agarose and stayed in the loading slots as a result of the superhelix density of closed circular baculovirus DNA being 
practically zero [12]. For restriction analysis, the DNA which was mainly a mixture of circular and covalently closed DNA, has been used. The amount of linear high molecular mass molecules was negligible.

\section{Estimation of molecular size of the SsMNPV genome}

Application of proper restriction enzymes for baculovirus DNA analysis was crucial for reliable DNA analysis, for accurate estimation of the SsMNPV genome size as well as for comparison of different virus populations appearing in Poland during several years. For screening of the products appearing after digestion with different restriction enzymes, we used the DNA-I, purified from isolate of 1978 . This viral DNA was digested with the following restriction enzymes: BamHI, SphI, PstI, EcoRI, XhoI, Ncol, SalI, HindIII and SacI. The electrophoretic pattern of restriction products (Fig. 1) shows that three restriction enzymes: BamHI, KpnI and EcoRI gave several high-molecular products, the size of which is difficult to estimate. On the other hand, two other enzymes: PstI and $\mathrm{Ncol}$, digested the genome DNA into many low-molecular mass fragments. For this reason the genome size was calculated on the basis of the restriction fragments obtained after digestion with two enzymes: HindIII and Xhol (Fig. $1,2)$, without taking into consideration the minor fragments. After adding the length of the products present after HindIII digestion we calculated the genome size to be $128.6 \mathrm{~kb}$. Asimilar calculation based on XhoI restriction fragments has shown that the genome size equals about $134 \mathrm{~kb}$. We also estimated the genome size of Autographa californica MNPV based on XhoI and HindIII (Fig. 2) restriction fragments to be about $130 \mathrm{~kb}$. This is in accordance with the data available for the size of AcMNPV DNA [13], which has been well characterized and the most thoroughly studied of baculoviral genomes.

\section{Comparison of restriction products from differ- ent SsMNPV isolates}

For restriction analysis of the genome from all four SsMNPV isolates (DNA-I-DNA-IV) collected in 1978-1989 the following endonucleases were used: HindIII (Fig. 3A), SacI (Fig. 3B) and ClaI (not shown). The electrophoretic patterns of HindIII digestion products of genome DNA from the four virus isolates $(a-d)$ were very similar. The DNA digestion products contained many minor fragments. The patterns of $\mathrm{SaCl}$ restriction products (Fig. 3B) showed some differences between the isolates. These differences concerned mainly the high molecular mass SacI fragments. DNA-I (d) and DNA-II (c) after restriction with $\mathrm{SacI}$ gave, in the range of higher molecular mass fragments, three fragments of $38 \mathrm{~kb}, 23 \mathrm{~kb}$ and $15 \mathrm{~kb}$ which were present in equimolar quantities. The $23 \mathrm{~kb}$ and $15 \mathrm{~kb}$ fragments became minor ones in DNA-III (b) and DNA-IV (a) after digestion with SacI (Fig. 3B, a-d). On the basis of the size of these two fragments and quantitative changes in the
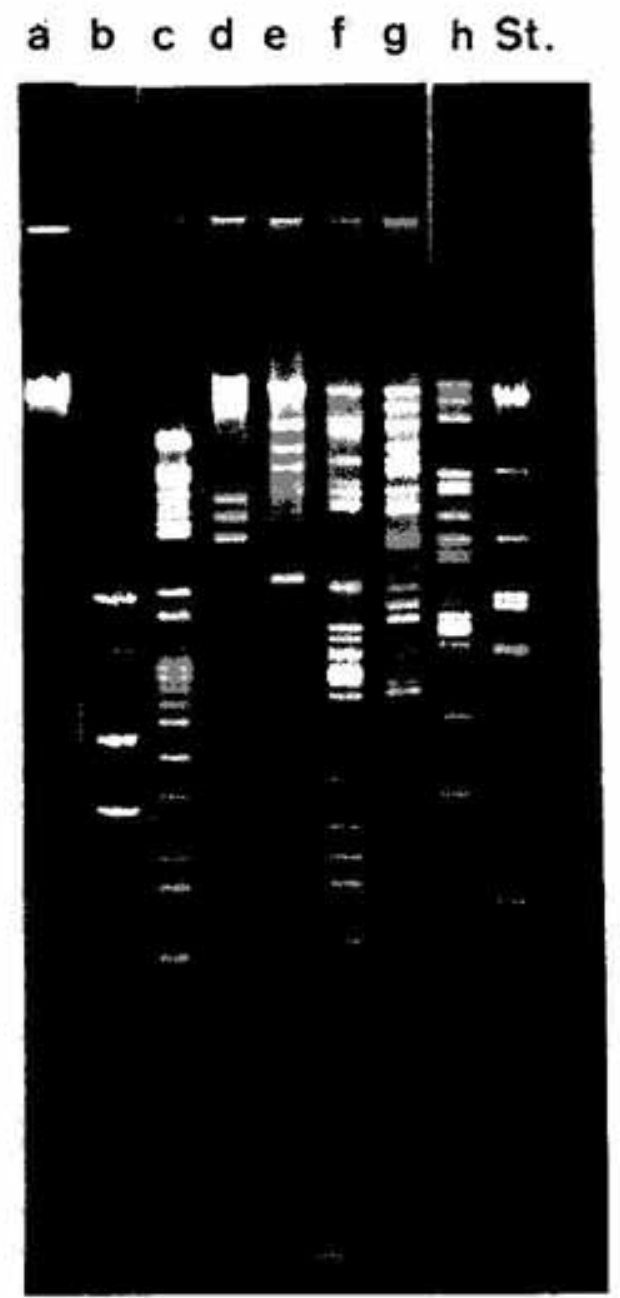

Fig. 1. Restriction endonuclease profile of Stilpnotia salicis nuclear polyhedrosis virus (SsMNPV) $D N A$, digested with the following enzymes: $\mathrm{BamHI}$ (a), PstI (b), NcoI (c), EcoRI (d), KpnI (e), HindIII (f), $\mathrm{XhoI}(\mathrm{g}), \mathrm{SacI}(h)$.

Digestion conditions as described in Methods. Standard (St) shows the mixture of $\lambda \mathrm{DNA} / \mathrm{HindIII}$ and $\lambda \mathrm{DNA} / \mathrm{E}$ CoRI. 


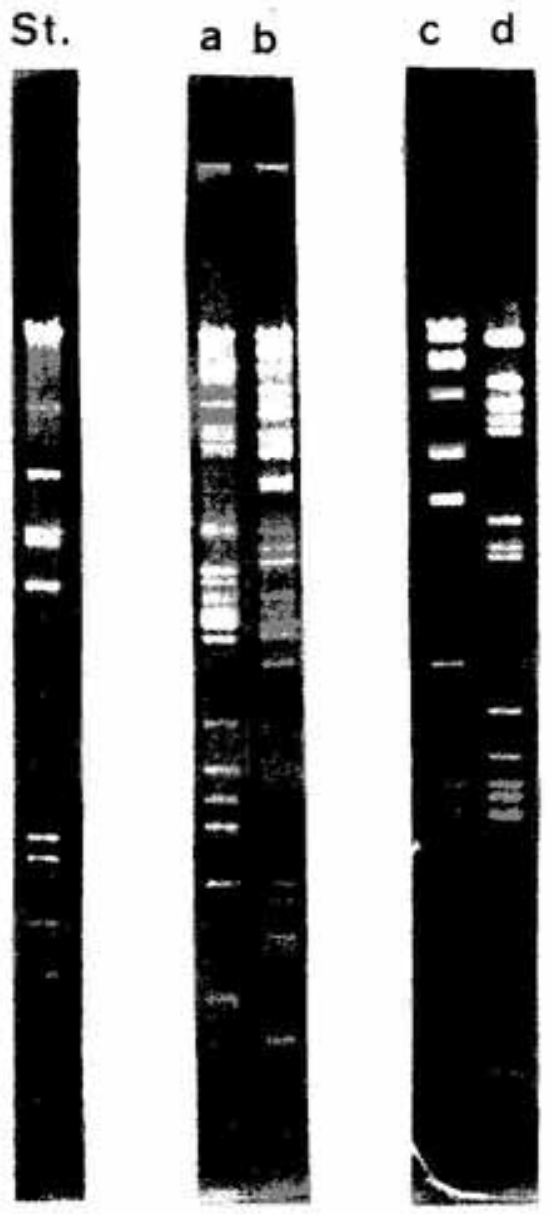

Fig. 2. Comparison of the HindIII (a) and Xhol (b) digestion fragments of SsMNPV DNA, isolate DNA-I, and XhoI (c) and HindIII (d) restriction fragments of Autographa californica nuclear polyhedrosis virus DNA.

Standard (St) as in Fig. 1. Digestion conditions were as described in Methods.

restriction pattern we can suggest that a new $\mathrm{Sacl}$ restriction site appeared in the $38 \mathrm{~kb}$ fragment in isolates DNA-III and DNA-IV. It should be pointed out that the presence of a high quantity of sub-molecular fragments did not result from partial digestion, as it can be observed with DNA probes treated with inappropriate restriction conditions (digestion time or amount of restriction enzyme).

The electrophoretic patterns of digestion products of HindIII, XhoI and ClaI endonucleases were closely similar whereas in the case of SacI the restriction products were more distinctly resolved. This enzyme may be a useful tool in identification and clone isolation of SsMNPV baculovirus.

\section{DISCUSSION}

The method for baculovirus DNA isolation directly from polyhedra, without purification of virions, was described by Cherepenko \& Martynenko [10]. Our modification of this method allowed to obtain an undegraded baculovirus DNA extracted from as small amount as $10^{9}$ polyhedra (or $10 \mathrm{mg}$ ) even without polyhedra purification, and suitable for restriction analysis. This modified procedure is based on turning the baculovirus DNA into supercoil form in the presence of ethidium bromide. Covalently closed virus molecules have no supercoiled structure at all, and it is necessary to stabilize such a structure with spermidine. Also the supercoil form makes possible to obtain the baculovirus DNA molecule in undegraded state on adjusting the $\mathrm{pH}$ to very high values by adding $\mathrm{NaOH}$. At this point double stranded linear DNA as well as open circular DNA were denatured and did not show their native structure when the $\mathrm{pH}$ was adjusted to 8.0 . Thus, the described procedure gives mainly DNA preparations without degraded molecules.

The electrophoretic pattern of different viral DNA preparations in agarose gel in the presence of ethidium bromide showed the presence of a small amount of the open circular and full-size linear molecules. Some degraded linear molecules appeared only occasionally. It should be stressed that the above method for viral DNA isolation is very useful but certain precautions should be taken, mainly at two steps of the procedure: 1 - adjusting the $\mathrm{pH}$ to 11.0, but not above that value; and $2-$ the mixture after adding each portion of $\mathrm{NaOH}$ should be stirred immediately, but very gently, to avoid high molecular mass DNA degradation. This procedure does not require introduction of RNase because RNA at a high $\mathrm{pH}$ is degraded.

The differences observed in restriction patterns of SsMNPV genome (Fig. 3B) are not surprising and can be also found in the case of other baculoviruses. It is known from the published data that AcMNPV strains, which are biologically identical, and also similar in the genome organization and nucleotide sequence 


\section{A}

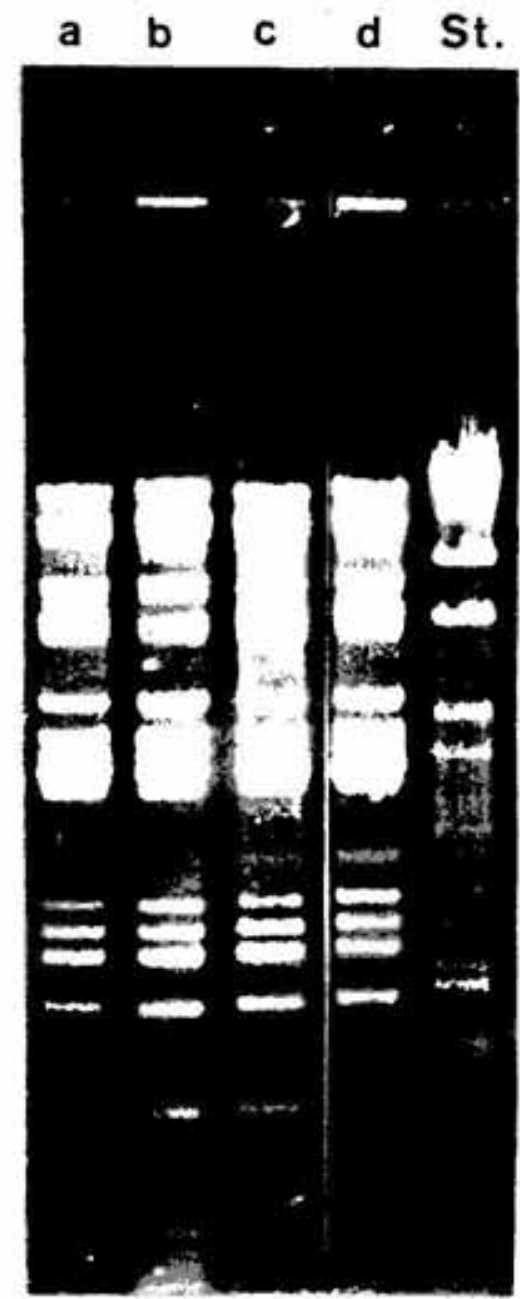

3B

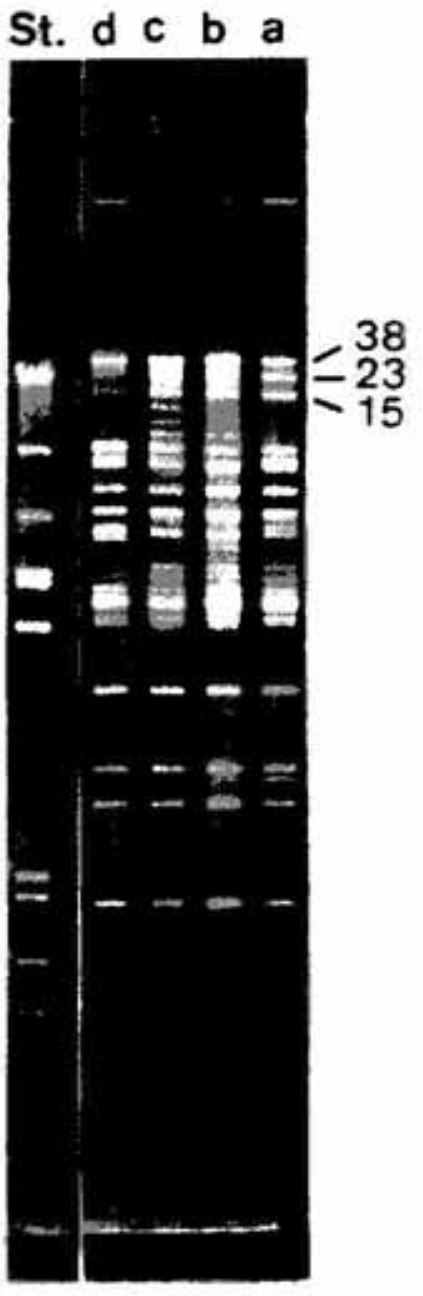

Fig. 3. Comparison of HindIII (A) and SacI (B) restriction products of SsMNPV, analysed in $0.7 \%$ agarose. DNA was isolated from four selected SsMNPV isolates, collected over 11 years: 1978 (DNA-I) - a, 1980 (DNA-II) - b, 1987 (DNA-III) - c, and 1989 (DNA-IV) - d.

in general, can differ in certain regions of the genome. For instance, strain L 1 and C 6 differ from $\mathrm{E} 2$ by the presence of an additional HindIII site in the HindIII fragment A. Also strain C 6 and HR 3 differ from L 1 and E 2 by a small insertion in the fragment HindIII C [13]. Genotypic variants have been studied in Mamestria brassicae MNPV [14] and Spodoptera frugiperda MNPV [15]. Baculovirus genomic variation was found to be restricted to defined regions, and three separate mechanisms for generating the variation were proposed. The genotypic variants could result from recombination [16], or acquisition of host cell DNA [17]. Other possible sources of genomic variants are muta- tions resulting in sequence deletion and/or reiteration within the viral genome. Both deletions and reiterations have been reported for baculoviruses propagated in vitro [18] and in vivo [19]. Further analysis of Stilpnotia salicis MNPV genome will allow to show the relationship of this poorly characterized virus to other multi-enveloped baculoviruses.

\section{REFERENCES}

1. OReally, D.R., Miller, L.K. \& Luckow, V.A. (1992) An overview of baculoviruses; in Baculovirus Expression Vectors; pp. 1-29, W.H. Freeman \& Co., New York. 
2. Summers, M. \& Anderson, D. (1972) Granulosis virus deoxyribonucleic acid: a closed double-stranded molecule. J. Virol, 9, 710-713.

3. Kool, M. \& Vlak, K.M. (1993) The structural and functional organization of the Autographa californica nuclear polyhedrosis virus genome. Arch. Virol. 130, 1-16.

4. Groner, A. (1986) Specificity and safety of baculoviruses; in Biology of Baculoviruses (Granados, R.R. \& Federici, B.A., eds.) vol. 1, pp. 177-202, CRC Press, Boca Raton, Fla.

5. Lameris, A.M.C., Ziemnicka, J., Peters, D., Grijpma, P. \& Vlak, J.M. (1985) Potential of baculoviruses for control of the satin moth, Leucoma salicis L. Med. Fac. Landbouww. Rijksuniv. Gent 50, 431-439.

6. Ziemnicka, J. (1981) Studies on nuclear and cytoplasmic polyhedrosis viruses of the satin moth (Stilpnotia salicis L.) (Lepidoptera, Lymantriidae). Prace Naukowe Instytutu Ochrony Roslin 23, 75-142.

7. Ziemnicka, J., Lipa, J.J., Czukrij, M.G., Wołoszczuk, L.F. \& Gyrlja, W.J. (1995) Pat. 165936. Entomopathogenic agent.

8. Smith, G.E. \& Summers, M.D. (1978) Analysis of baculovirus genomes with restriction endonucleases. Virology 89, 517-527.

9. Fuxa, J.R., Maruniak, J.E. \& Richter, A.R. (1994) Characterization of the DNA of a nuclear polyhedrosis virus selected for an increased rate of the vertical transmission. J. Invertebr. Pathol. 64, 1-5.

10. Cherepenko, E.I. \& Martynenko, E.I. (1985) A simple method for baculovirus DNA isolation. Molec. Biol. 18, 1519-1524 (in Russian).

11. Strokovskaya, L.I. (1981) The method of agarose gel electrophoresis for characterization of high molecular weight baculovirus DNA; in Entomopathogenic Viruses and its Application; pp. 19-24, Naukova dumka, Kiev (in Russian).

12. Revet, B.M.J. \& Guelpa, B. (1979) The genome of baculovirus infecting Tipula peludosa (Meig) (Diptera): a high molecular weight closed circular DNA of zero superhelix density. Virology 96, 633-639.

13. Ayres, M.D., Howard, S.C., Kuzio, J., Lopez-Ferber, M., Possee, R. (1994) The complete DNA sequence of Autographa californica nuclear polyhedrosis virus. Virology 902, 586-605.

14. Brown, D.A., Evans, H.F., Allen, C.J. \& Kelly, D.C. (1981) Biological and biochemical investigations of five European isolates of Mamestra brassicae nuclear polyhedrosis virus. Arch. Virol. 69, 209-217.
15. Knell, J.D. \& Summers, M.D. (1981) Investigation of genetic heterogeneity in wild isolates of Spodoptera frugiperda nuclear polyhedrosis virus by restriction endonuclease analysis of plaque-purified variants. Virology 112, 190-197.

16. Summers, M.D., Smith, G.E., Knell, J.D. \& Burand, J.P. (1980) Physical maps of Autographa californica and Rachiplusia ou nuclear polyhedrosis virus recombinants. J. Virol. 34, 693-703.

17. Fraser, M.J., Smith, G.E. \& Summers, M.D. (1983) Acquisition of host cell DNA sequences by baculoviruses: Relationship between host DNA insertions and FP mutants of Autographa californica and Galleria mellonella nuclear polyhedrosis viruses. J. Virol. 47, 287-300.

18. Burand, J.P. \& Summers, M.D. (1982) Alteration of Autographa californica nuclear polyhedrosis virus DNA upon serial passage in cell culture. Virology 119, 223-229.

19. McIntosh, A.H. \& Ignoffo, C.M. (1986) Restriction endonuclease cleavage patterns of commercial and serially passaged isolates of Heliothis baculovirus. Intervirology 41, 172- 176. 